\title{
A Comparison of Self-Leadership Characteristics of the Students of Department of Fine Arts and the Others "The Case of Gazi University"
}

\author{
Dilek Özçelik Herdem
}

Gazi University Faculty of Education, 06215, Ankara, Turkey

Copyright $(2019$ by authors, all rights reserved. Authors agree that this article remains permanently open access under the terms of the Creative Commons Attribution License 4.0 International License

\begin{abstract}
This study aims to examine the differences in the perception of self-leadership of the students studying in the department of fine arts and in the 0 other departments of the faculty of education. In the study, survey method was used as data collection method. The sample of the research consisted of 604 students. SPSS and AMOS software programs were employed to analyze data. Confirmatory factor analysis was performed for the validity of the scale, and Cronbach Alpha was computed to test the reliability. In the study, descriptive statistics were displayed, and independent sample t-test as well as one-way analysis of variance (ANOVA) were used to test the hypotheses of the study. According to the findings of the research, self-leadership differs by gender and department of the students. It is suggested that efforts should be made to start developing self-leadership skills of the students, in particular male students.
\end{abstract}

Keywords Self-leadership, Education, Fine Arts Education, Music Education, Arts (Painting) Education

\section{Introduction}

Learning environment is ever changing in compliance with $21^{\text {st }}$ century skills declared by United Nations as well as technological advances especially with industrial revolution and drastic changes in every aspect of life. Teacher centric learning replaced by learner centric one. This century requires a new teacher profile that identifies the capabilities of the learners and serves each on their different skills. Therefore, teacher candidates are to gain new abilities to work in this differentiated learning environment. It is of great significance that teacher have high psychological and social capital as well as intelligence in today's complex world nurtured with creativity and entrepreneurship. Toward this end, teacher candidates need to know themselves well, to discover their competencies, and to empower themselves.

Also, keeping in mind that students take the teachers as a role model, the teachers are expected to lead and guide the students by means of their knowledge, skills, and abilities. In particular, competencies of the teachers affect and direct those of the students studying music, arts, and sports. In this respect, gaining soft skills such as communication, teamwork, social capital, and critical thinking are attracted great attention. The teachers developed themselves would create the learning environment that stimulates creativity and innovativeness of the students.

To our best understanding, there are scant literature on personality of the teachers because of roles and responsibilities. To this end, self-leadership as well as personality is the one attracted more researchers' attention to discover the self and then improve weaknesses [1]. Many of studies aim to reveal the leadership potential that exists within the teacher and to emphasize the inner motivation [2]. Besides, it is of great significance for individuals to motivate and lead themselves.

Leadership theory is ample, however some mixed. Each study has brought a new perspective and explanation to the leadership literature, and many factors related to leadership gathered as a result of the studies. In compliance with the number of studies, there are a large number of definitions brought by the researchers. Towards this end, leadership definitions mainly focus on the leaders' influence on others, charisma, and their characteristics perceived by their followers. However, self-leadership, frequently discussed in recent years, is regarded as a concept that goes beyond these definitions. Self-leadership, first proposed in literature by Manz [3], is defined as "one's self-motivation and self-direction process in order to achieve personal and organizational desired end state". The concept of self-leadership, is also referred to as super leadership in the literature, represents an individual-level perspective that emerges through the self-influence of individuals to control their actions and thoughts [4].

It is understood that the concept of self-leadership is a 
neglected topic in the management. Leaders try to motivate their employees and to align their behavior with organizational objectives. However, not provided required resources by employees that they are totally expected to work hard to ensure organizational effectiveness. This is not wrong since human capital is the most important asset in organizations. Therefore, self-led responsibilities and autonomy possibilities will become much more significance in near future [2].

In addition, although there are many conceptual studies on self-leadership since Manz and colleagues introduced the concept, there is a scant literature regarding empiric studies supporting the conceptual model [5-7]. Following issuing a reliable measure by Houghton \& Neck [8], self-leadership studies became more attractive for the researchers. And then, cross-cultural validation is made by many researchers [9-16].

This fact, without doubt, is also very important in teacher education institutions. It is thought crucial for future teacher candidates to adopt self-leadership skills and to improve themselves in order to be successful at their professional experiences and to be role models for their students. The teacher is primarily a person with a high sense of responsibility. In this respect, teachers should be able to motivate themselves and by developing suitable strategies they should guide both the students and themselves. Therefore it is obvious that determining and improving teacher candidates' self-leadership skills is significant. Towards this end, this study aims at determining self-leadership level of the students studying teaching at Faculty of Educations, making a comparative analysis of the self-leadership perceptions of the students in the department of fine arts and other departments. In addition, whether self-leadership differed by gender, division, academic achievement, and the status of playing an instrument.

\section{Theoretical Framework}

It is observed that individual self-control is more effective than organizational controls [3]. We may relate self-control with cognitive strategies and intrinsic motivation [3]. Self-leadership consists of a series of specific behaviors and cognitive strategies designed to create a positive effect on personal effectiveness. In this sense, the self-leadership strategies are divided into three groups; behavioral strategies, natural reward strategies and constructive thinking model strategies [5]. Behavioral strategies inspire the self through positive behaviors resulting in success [8]. Goal setting, self-monitoring, clues, and self-rewarding/punishing are basic strategies employed [2]. By making self-assessment, individuals take a journey into their inner field and invent themselves [17]. This is alike an individual SWOT analysis to develop the self. By means of analysis, person gives concrete time-oriented goals that challenge the self. Self-focused observations urge the one to reach the goals [18]. Self-rewarding is the prize for completing a task as a milestone through the goals [16]. Rewards facilitate and encourage the self to get deliberate results make us more effective and efficient [17]. Moreover, self-punishment is not a negative stressor on the self. It is a lessons-learned and a risk management tool that hinders the self-making the same mistakes. Therefore, some reminders may be used to as clues for not making mistakes. Self-cueing is a kind of memory aid service to facilitate setting the goals [19].

Natural reward strategies are beneficial to make the tasks enjoyable [8]. While the natural reward strategies are process-oriented, self-rewarding focuses on the results [16]. Persons make natural reward strategies use of making their hob more attractive [17].

Constructive thinking model strategies, as a third component, are aiming at changing the mindset of the self [20]. It may not be wrong to state that constructive thinking model strategies are the ones to control and manage the one's own mentality [21]. Developing constructive thinking model is composed of three sub-dimensions: desiring successful performance by determining goals, self-talking and assessing own thoughts and ideas [16]. These strategies are the positive reinforces of self-leadership. Hence, former two strategies are designed to influence personal effectiveness positively by helping individuals to be conscious of their own behaviors and thoughts [22].

\section{Research Method}

In the research, the differences between the self-leadership perceptions of fine arts students and students in other departments are examined. For this purpose, firstly student's self-leadership perceptions are determined and later the differences regarding department, academic achievement, gender, and the status of playing an instrument. The research hypotheses are listed below.

H1: Students' self-leadership perceptions differ according to their departments.

H2: Students' self-leadership perceptions differ according to their academic achievement.

H3: Students' self-leadership perceptions differ according to their gender.

H4: Self-leadership perceptions of students in other departments differ according to the status of playing an instrument.

In the following part of the study, the sample of the study and the participant information, the measurement tools employed in the research, the analyses, and the findings are discussed respectively.

\subsection{Study Group}

There are 2564 students enrolled in the Faculty of Education in the 2017-2018 Academic Year. All students 
in the faculty were asked for completing the survey form, but 604 of the students returned the questionnaires. In this case, the return rate was $23.55 \%$. The number of the sample at the significance level of $5 \%$ with a confidence interval of $5 \%$ is determined as 334 [9]. Hence, the sample is considered adequate to represent the population. Descriptive statistics regarding demographic variables are given in the following tables.

The frequency distribution of the departments of students is given in Table 1. While 272 (45.0\%) students study in the Department of Fine Arts, 332 (55.0\%) students study in other departments. The number of students studying in the Music Teaching Department of Fine Arts is $116(19.2 \%)$, while the number of students studying in art teaching is 156 (25.8\%). The numbers of students studying different fields are as follows: Arabic Teaching -70 (11,6\%), Physical Education Teaching-49 (8,1\%), French Teaching-89 (14,7\%), English Teaching is 35 (5,8\%), Special Education Teaching-18 (3,0\%), and Turkish Teaching-71 (11,8\%).

Table 1. Departments of Students

\begin{tabular}{|c|c|c|c|c|c|}
\hline & & Frequency & $\%$ & Frequency & $\%$ \\
\hline \multirow{2}{*}{$\begin{array}{l}\text { Fine } \\
\text { Arts }\end{array}$} & $\begin{array}{c}\text { Music } \\
\text { Teaching }\end{array}$ & 116 & 19,2 & \multirow{2}{*}{272} & \multirow{2}{*}{45,0} \\
\hline & Art teaching & 156 & 25,8 & & \\
\hline \multirow{6}{*}{ Other } & $\begin{array}{c}\text { Arabic } \\
\text { Teaching }\end{array}$ & 70 & 11,6 & \multirow{6}{*}{332} & \multirow{6}{*}{55,0} \\
\hline & $\begin{array}{c}\text { Physical } \\
\text { Education } \\
\text { Teaching }\end{array}$ & 49 & 8,1 & & \\
\hline & $\begin{array}{c}\text { French } \\
\text { Teaching } \\
\end{array}$ & 89 & 14,7 & & \\
\hline & $\begin{array}{c}\text { English } \\
\text { Teaching }\end{array}$ & 35 & 5,8 & & \\
\hline & $\begin{array}{c}\text { Special } \\
\text { Education } \\
\text { Teaching }\end{array}$ & 18 & 3,0 & & \\
\hline & $\begin{array}{c}\text { Turkish } \\
\text { Teaching }\end{array}$ & 71 & 11,8 & & \\
\hline \multicolumn{2}{|r|}{ Total } & 604 & 100,0 & 604 & 100,0 \\
\hline
\end{tabular}

The frequency of the students by gender is given in Table 2. 212 of the students are male $(35,1 \%)$ while 392 of the students are female (64,9\%).

Table 2. 1 Students' Gender

\begin{tabular}{|c|c|c|c|}
\hline & Frequency & $\%$ & Cumulative \% \\
\hline Male & 212 & 35,1 & 35,1 \\
\hline Female & 392 & 64,9 & 100,0 \\
\hline Total & 604 & 100,0 & \\
\hline
\end{tabular}

The frequency of the students by class is given in Table 3 . The number of freshman is $208(34,4 \%)$, the number of sophomore is $143(23,7 \%)$, the number of middler is 150 $(24,8 \%)$, and that of senior is $103(17,1 \%)$.
Table 3. Students' Attending Class 2

\begin{tabular}{|c|c|c|c|}
\hline & Frequency & $\%$ & Cumulative \% \\
\hline Freshman & 208 & 34,4 & 34,4 \\
\hline Sophomore & 143 & 23,7 & 58,1 \\
\hline Middler & 150 & 24,8 & 82,9 \\
\hline Senior & 103 & 17,1 & 100,0 \\
\hline Total & 604 & 100,0 & \\
\hline
\end{tabular}

The frequency of the students by academic achievement level is given in Table 4. Students with an academic success of 90 points or more were considered to be adequate, and those below 90 were considered to be improved. In this case, $176(29,1 \%)$ of the students were considered as adequate, while $428(70,9 \%)$ of the students were considered as need to be improved.

Table 4. 3 Students’ Academic Achievement

\begin{tabular}{|c|c|c|c|}
\hline & Frequency & $\%$ & Cumulative \% \\
\hline To be improved & 428 & 70,9 & 70,9 \\
\hline Adequate & 176 & 29,1 & 100,0 \\
\hline Total & 604 & 100,0 & \\
\hline
\end{tabular}

Frequency table of the students playing instrument of other departments is given in Table 5. While 57 (17,2\%) of the students studying at other departments play an instrument, $275(82,8 \%)$ of them does not play any instrument.

Table 5.4 Students Playing an Instrument

\begin{tabular}{|c|c|c|c|}
\hline & Frequency & $\%$ & Cumulative \% \\
\hline Playing an Instrument & 57 & 17,2 & 70,9 \\
\hline $\begin{array}{c}\text { Not Playing an } \\
\text { Instrument }\end{array}$ & 275 & 82,8 & 100,0 \\
\hline Total & 332 & 100,0 & \\
\hline
\end{tabular}

\subsection{Questionnaire}

Data on self-leadership and demographic information were gathered through self-reported questionnaire. Studies of Validity and reliability of the self-leadership scale were previously making by Tabak et al. [16]. The scale developed by Manz [23] and revised by Houghton and Neck [8] consists of 35 items, 3 dimensions, and 9 factors. As a result of the study conducted by Tabak et al. [16], the scale adapted to Turkish consists of 29 items, 3 dimensions and 8 factors. The first dimension titled behavior-oriented strategies consists of three sub-factors as self-rewarding (three items), self-punishment (four items), self-observation (four items), and setting clues (two items). The second dimension called natural awards strategies is composed of two items. The third dimension titled constructive thought pattern strategies is composed of factors as desiring successful performance by defining own goals (seven items), self-talk (three items), thoughts / assumptions evaluation (four items) [16]. In the 5-point Likert scale, the respondents are asked to mark the frequency of the behaviors specified in the expressions $(1=$ Never, 2 = Rarely, 3 = Occasionally, 4 = Usually, 5 = Always) 
In this study, the construct validity was analyzed by confirmatory factor analysis (CFA) and the reliability was tested by reliability analysis (Cronbach Alpha coefficient). The second-level multi-factor model for the measuring instrument is shown in Figure 1. CFA results are shown in Table 6, and the results of the reliability analysis are given in Table 7 . When the CFA results of the self-leadership scale are examined, it is observed that the fit index values of the second level multifactor model are not within acceptable limits [24]. Therefore, modification indexes are thoroughly examined. By subtracting questions numbered 1, 24, and 26 from the self-leadership scale, the model is modified. Thus, the fit index values of the scale became within acceptable limits.

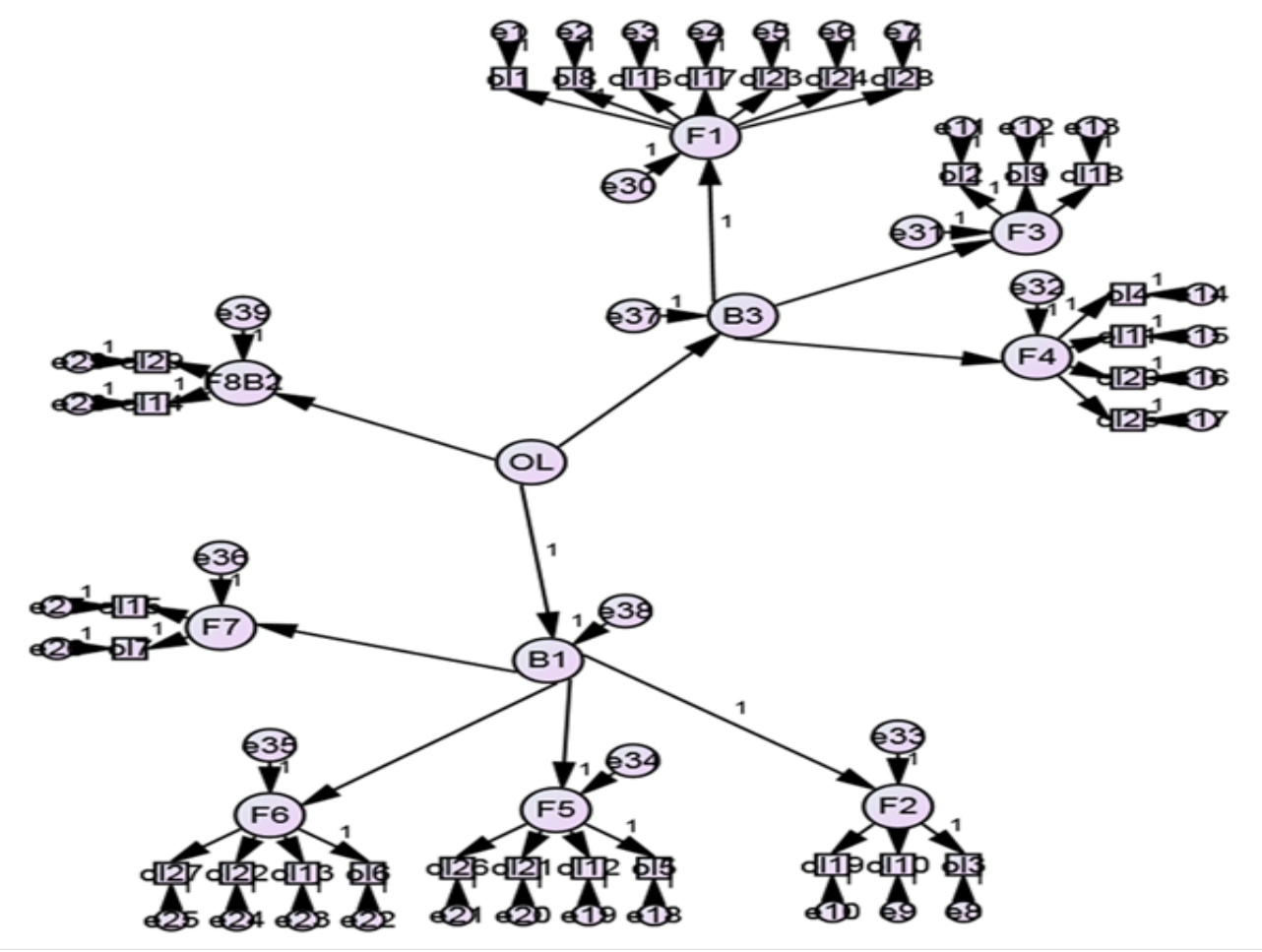

Figure 1. Second-level Multi-Factor Model

Table 56. Self-leadership Scale CFA Results

\begin{tabular}{|c|c|c|c|c|c|c|c|c|}
\hline & $\chi^{2}$ & s.d. & $\chi^{2} /$ s.d. & RMR & IFI & TLI & CFI & RMSEA \\
\hline Second Level Multi-Factor Model & 1414,697 & 367 & 3,855 & 0,065 & 0,857 & 0,842 & 0,857 & 0,069 \\
\hline Modified Model & 819,915 & 283 & 2,897 & 0,055 & 0,914 & 0,901 & 0,914 & 0,056 \\
\hline
\end{tabular}

$\chi^{2}$ : Chi-square; s.d .: degree of freedom; RMR: root mean square residual; IFI: Bollenments Incremental Fit Index; TLI: Tucker-Lewis Index; CFI: Bentler Compars Comparative Fit Index; RMSEA Root Mean Square Error of Approximation.

The modified second-level multi-factor structure of the self-leadership scale is given in Figure 2. The fit index values of the scale are given in Table $6\left(\chi^{2} /\right.$ s.d. $=2,897$; RMR $=0,055$; IFI = 0,914; TLI = 0,901; CFI =0,911; RMSEA =0,056; $\mathrm{p}=$ $0,000)$. In this case, the results of reliability analysis of the self-leadership scale, in general, based on size and factor were obtained as shown in Table 7.

Table 7.6 Self-leadership Scale Reliability Analysis Result

\begin{tabular}{|c|c|c|c|c|c|c|c|c|c|c|}
\hline General & Dimension 1 & $\begin{array}{c}\text { Dimension 2 } \\
\text { (Factor 8) }\end{array}$ & Dimension 3 & Factor & Factor 2 & $\begin{array}{c}\text { Factor } \\
3\end{array}$ & $\begin{array}{c}\text { Factor } \\
4\end{array}$ & $\begin{array}{c}\text { Factor } \\
5\end{array}$ & $\begin{array}{c}\text { Factor } \\
6\end{array}$ & $\begin{array}{c}\text { Factor } \\
7\end{array}$ \\
\hline 0,911 & 0,867 & 0,457 & 0,792 & 0,814 & 0,843 & 0,762 & 0,730 & 0,688 & 0,698 & 0,744 \\
\hline
\end{tabular}

When the validity and reliability analysis of the self-leadership scale are considered together, it is understood that it is more appropriate to consider the self-leadership as one factor in this study. Because, according to CFA, the second level multifactorial structure was confirmed, and the Cronbach's alpha of the scale was found as 0,911. In addition, when the reliability analysis results in Table 7 are examined, some factors with low reliabilities are observed. 


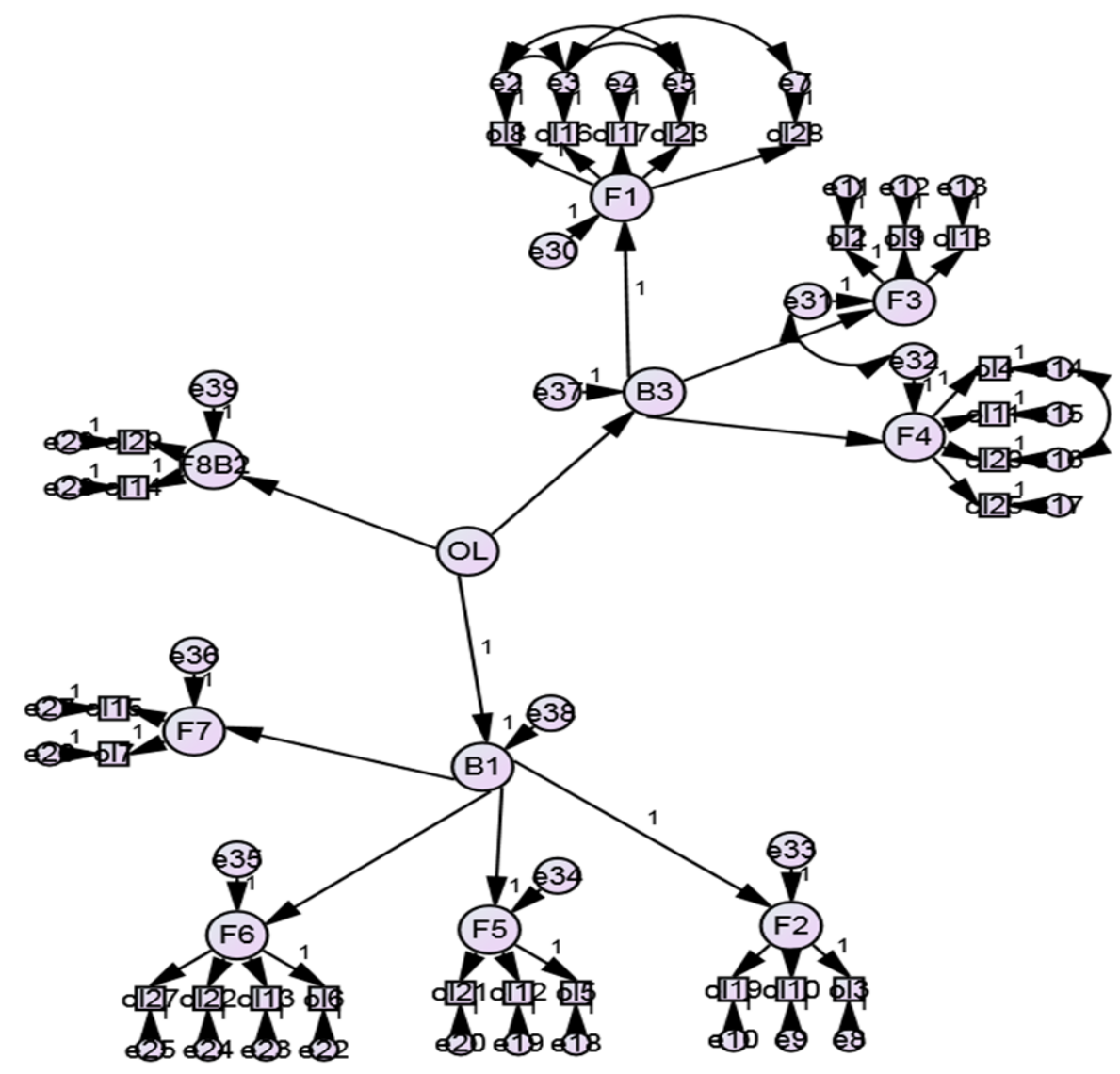

Figure 2. Modified Secnd-level Multi-Factor Model

\section{Findings}

After the validity and reliability studies of the scale employed in the study were completed, hypothesis tests were conducted to verify the research hypotheses. To test the hypotheses, independent sample t-test and one-way analysis of variance (ANOVA) were employed in the study.

The results of the hypotheses tests to determine whether the self-leadership of the students differ by demographic variables are listed in the following tables respectively.

Table 78. Self-leadership Perceptions of Students According to Departments

\begin{tabular}{|c|c|c|c|c|c|c|}
\hline Student's Department & $\mathrm{N}$ & Mean & s.d. & Differentiation & $\mathrm{F}$ & $\mathrm{p}$ \\
\hline Music Education & 116 & 3,73 & 0,60 & -- & \multirow[t]{9}{*}{3,562} & \multirow[t]{9}{*}{0,00} \\
\hline Art Teaching & 156 & 3,89 & 0,51 & Physical Education Teaching & & \\
\hline French Teaching & 70 & 3,77 & 0,54 & --- & & \\
\hline English Language Teaching & 49 & 3,97 & 0,39 & Physical Education Teaching & & \\
\hline Turkish Language Teaching & 89 & 3,90 & 0,60 & Physical Education Teaching & & \\
\hline Physical Education Teaching & 35 & 3,47 & 0,85 & $\begin{array}{c}\text { Art Teaching } \\
\text { English Teaching } \\
\text { Turkish Teaching }\end{array}$ & & \\
\hline Arabic Language Teaching & 18 & 3,91 & 0,41 & -- & & \\
\hline Special Education Teaching & 71 & 3,82 & 0,54 & --- & & \\
\hline Total & 604 & 3,82 & 0,57 & --- & & \\
\hline
\end{tabular}


The results of one way ANOVA to determine whether the self-leadership of students differ by the department they study are given in Table 8. When Table 8 is examined, it can be seen that students' perceptions of self-leadership significantly differ according to their departments. Hence, it may be concluded that $\mathrm{H} 1$ is supported. Post-hoc analysis was made to determine which departments differ. At first, homogeneity of variances was tested, and it was assumed that the variances were not equal (Levene statistical value $=$ 4,767; $p=0,000$ ). To this end, Games Howell test was preferred as Post-Hoc analysis method and differences among groups were determined by means of further analysis and shown in Table 8. Self-leadership perceptions of the students studying Physical Education Teaching (mean $=3,47$, s.d. $=0,85$ ) is significantly lower than those studying Art Teaching (mean $=3,89$, s.d. $=0,51$ ), English Teaching (mean $=3,97$, s.d. $=0,39$ ) and Turkish Teaching (mean $=3,90$, s.d. $=0,60$ ).

Table 9. 8 Self-leadership Perceptions of Students According to Academic Achievment

\begin{tabular}{|c|c|c|c|c|c|}
\hline $\begin{array}{c}\text { Student's } \\
\text { Academic } \\
\text { Achievement }\end{array}$ & $\mathrm{N}$ & Mean & s.d. & $\mathrm{t}$ & $\begin{array}{c}\mathrm{p} \\
\text { (two-tailed) }\end{array}$ \\
\hline $\begin{array}{c}\text { Open to } \\
\text { Development }\end{array}$ & 428 & 3,82 & 0,58 & 0,061 & 0,951 \\
\cline { 1 - 3 } $\begin{array}{c}\text { Have Adequate } \\
\text { Development }\end{array}$ & 176 & 3,82 & 0,56 & & \\
\hline
\end{tabular}

The students are grouped into two categories; the ones having adequate development and others open to development. Self-leadership perceptions of students according to academic achievement are tested by means of independent sample t-test to determine whether the students' perceptions differ by academic achievement. When Table 9 is examined, it is seen that there is no statistically significant difference between the students who are open to development and those who have adequate development. Thus, it may be concluded that H2 is rejected.

Self-leadership perceptions of students according to gender are tested by means of independent sample t-test to determine whether the students' perceptions differ by gender.

Table 10.9 Self-leadership Perceptions of Students According to Gender

\begin{tabular}{|c|c|c|c|c|c|}
\hline $\begin{array}{c}\text { Student's } \\
\text { Gender }\end{array}$ & $\mathrm{N}$ & Mean & s.d. & $\mathrm{t}$ & $\begin{array}{c}\mathrm{p} \\
\text { (two-tailed) }\end{array}$ \\
\hline Male & 212 & 3,73 & 0,59 & \multirow{2}{*}{$-2,986$} & 0,003 \\
\hline Female & 392 & 3,87 & 0,56 & & \\
\hline
\end{tabular}

When Table 10 is examined, it is seen that self-leadership perceptions of male students are statistically significantly lower than female students. Hence, it may be concluded that H3 is supported.

Self-leadership perceptions of students according to the status of playing an instrument is tested by means of independent sample t-test to determine whether the students' perceptions differ by the status of playing an instrument. When Table 11 is examined, it is seen that self-leadership perceptions of students who do not play instruments are lower than those who play instruments and this difference is not statistically significant. Hence, it may be concluded that $\mathrm{H} 4$ is not supported.

Table 11.10 Self-leadership Perceptions of Other Department Students According to Playing an Instrument

\begin{tabular}{|c|c|c|c|c|c|}
\hline $\begin{array}{c}\text { Status of Playing } \\
\text { an Instrument }\end{array}$ & $\mathrm{N}$ & Mean & s.d. & $\mathrm{t}$ & $\begin{array}{c}\mathrm{p} \\
\text { (two-tailed) }\end{array}$ \\
\hline $\begin{array}{c}\text { Not Playing an } \\
\text { Instrument }\end{array}$ & 275 & 3,81 & 0,56 & & \\
\hline $\begin{array}{c}\text { Not Playing an } \\
\text { Instrument }\end{array}$ & 57 & 3,90 & 0,70 & $-1,061$ & 0,290 \\
\hline
\end{tabular}

\section{Discussion and Conclusion}

Some roles and responsibilities of the teachers are, but not limited to, guiding the students the students regarding career through their skills and abilities, ensuring their adaptation to the life for creating welfare by means of creativity, and teaching them how to transfer knowledge into practice [25].

To our best understanding, there are scant literature on personality of the teachers because of roles and responsibilities. However, self-leadership as well as personality is the one attracted more researchers' attention to discover the self and then improve weaknesses [1]. Towards this end, self-leadership perceptions of students are determined, and whether the variables differ according to demographic factors are investigated in this study. CFA was employed to confirm the structural validity of the measurement tool used in the study, and Cronbach Alpha coefficient was used for the reliability. As a result of CFA, it was determined that it would be appropriate to consider self-leadership in total. Provided that this validated construct is in compliance with the one adapted by Tabak et al. [16], the second-level multifactorial structure of self-leadership was confirmed.

The research hypotheses were tested to determine whether students' self-perceptions of leadership differ according to department, academic success, gender, and the status of playing an instrument. According to the results of independent sample t-test and one-way ANOVA analyses, it is conceded that self-perception of students' leadership do not differ by academic achievement and the status of playing an instrument but differ by the department and gender. Considering students' departments, self-leadership perceptions of students studying Physical Education Teaching are significantly lower than students studying Art Teaching, English Teaching, and Turkish Teaching. In terms of gender, it is found out that male students' self-leadership perceptions are statistically significantly lower than those of female students.

Self-leadership is defined by Manz [3] as individual's intrinsic motivation process to direct the one through success. As emphasized by Neck and Houghton [5], 
self-leadership is based on motivation theories. However, self-leadership fed by inner motivation is a main determinant of motivational outcomes such as self-efficacy, self-regulation, individual performance, mindfulness, and happiness [19,20,26,27]. Garipağaoğlu and Güloğlu [28] report that learned resourcefulness and locus of control are predictors of self-leadership. According to the research, it is pointed out that the candidates who are choose to be teacher at their discretion have higher self-leadership once they have learned-strength and they are more internal control.

The findings of the study indicate that the means of self-leadership in our study is 3.82 over 5 points. It is in compliance with prior studies [21,29-31]. However, there is statistically significant difference among the students studying education faculty. The highest mean is 3.97 of the students studying English teaching, while the lowest score is 3.47 of the ones studying physical education teaching. The high level of self-leadership scores of the English Teaching Department shows that the students studying English teaching are more successful in terms of self-direction and motivation. Another finding in the study is that self-leadership does not differ by academic achievement. Likewise, it is concluded that self-leadership does not differ by playing an instrument, either.

When the results of both the current research findings and the other studies in the literature are examined, the importance of the concept self-leadership and its relationship with various variables are understood. The inclusion of different variables affecting the self-leadership skills in future studies on teacher candidates will bring a different perspective to the literature on self-leadership. In addition, when it is considered in the context of students, it can be encouraged to focus on achievements rather than on academic success and to use self-leadership and thus internal motivation to develop soft skills. From this point of view, it is highly recommended that future studies on self-leadership focus on determinants and measures to develop the skills of the teacher candidates since they are the role-model for the students. In particular, the researchers are highly recommended to study the relation between self-leadership and $21^{\text {st }}$ century skills such as mindfulness, critical thinking, and analytical thinking. As role-models of the students, teacher need to equip with convenient tools to grow them for future challenging competitive world.

On the other hand, there are some limitations to keep in mind while generalizing the findings of the study. At first, the sample of the study is from the students studying at Faculty of Education. This limitation is twofold. One is the sample is consisted of the students, and next, the students study at teaching. That's why the findings may be bound by the sample. Second, perceptions of the students are measured in a cross-sectional design. Thus, the findings are related to the psychology for the participants at the time measured. Last, but not least, perceptions are subject to social desirability that participants may answer as they would be instead not actually they are. Therefore, we recommend the researchers, practitioners, and academicians to make more researches on self-perception to overcome the limitations, thus to make contributions to the literature.

\section{REFERENCES}

[1] M.R. Furtner, J. F. Rauthmann, P. Sachse. The socioemotionally intelligent self-leader: Examining relations between self-leadership and socioemotional intelligence. Social Behavior and Personality: an international journal, 38(9), 1191-1196, 2010.

[2] S. Doğan, F. Şahin. Bireysel Performansı Ve Verimliliği Artımada Kendi Kendine Liderlik Yaklaşımının Önemi. ISGUC The Journal of Industrial Relations and Human Resources, 10(1), 77-95, 2008.

[3] C.C. Manz. Self-Leadership: Toward an Expanded Theory of Self- Influence Processes in Organizations. Academy of Management Review, 11(3), 585-600, 1986.

[4] Ö. Uğurluoğlu. Kendi Kendine Liderlik Stratejileri Üzerine Bir Araştırma. Atatürk University Journal of Economics and Administrative Sciences, 24 (1), 2010.

[5] C.P. Neck, J.D. Houghton. Two decades of self-leader sponsorship theory and research: Past developments, present trends, and future possibilities. Journal of managerial psychology, 21 (4), 270-295, 2006

[6] G.L. Stewart, S.H. Courtright, C.C. Manz, Self-leadership: A multilevel review. Journal of Management, 37(1):185222, 2011.

[7] P. Andressen, U. Konradt, C.P. Neck. The relation between self-leadership and transformational leadership: Competing models and the moderating role of virtuality. Journal of Leadership \& Organizational Studies, 19(1), 68-82, 2012.

[8] J.D. Houghton, C.P. Neck. The revised self-leadership questionnaire: Testing a hierarchical factor structure for self-leadership. Journal of Managerial psychology, 17(8), 672-691, 2002.

[9] A. Carmeli, R. Meitar, J. Weisberg. Self-leadership skills and innovative behavior at work. International Journal of Manpower, 27(1), 75-90, 2006.

[10] G.F. Müller. Dimensions of self-leadership: A German replication and extension. Psychological reports, 99(2), 357-362, 2006.

[11] P. Andreßen, U. Konradt. Messung von Selbstführung: Psychometrische Überprüfung der deutschsprachigen Version des Revised Self-Leadership Questionnaire. Zeitschrift für Personal psychologie, 6(3), 117-128, 2007.

[12] J. Ho, P.L. Nesbit. A refinement and extension of the self-leadership scale for the Chinese context. Journal of Managerial Psychology, 24(5), 450-476, 2009.

[13] J. Ho, P.L. Nesbit. Self-Leadership in a Chinese Context: 
Work Outcomes and the Moderating Role of Job Autonomy, Group \& Organization Management, 39 (4), 389-415, 2014.

[14] P. Marques-Quinteiro, L.A. Curral, A.M. Passos. Adapting The Revised Self-Leadership Questionnaire to The Portuguese Context, Social indicators research, 108 (3), 553-564, 2012.

[15] B. Mahembe, A. Engelbrecht, Z. Wakelin. A study to assess the reliability and construct validity of the Abbreviated Self-leadership Questionnaire: a South African study, South African Journal of Psychology, 47(3) 356-366, 2013.

[16] A. Tabak, Ü. Sığrı, T. Türköz. Öz Liderlik Ölçeğinin Türkçeye Uyarlanması Çalışması. Bilig, 67, 213-246, 2013.

[17] [17] C.C. Manz, H.P. Sims. The new superleadership: Leading others to lead themselves. Berrett-Koehler Publishers, 2001.

[18] Furtner, M. R., Tutzer, L., Sachse, P. The mindful self-leader: Investigating the relationships between self-leadership and mindfulness. Social Behavior and Personality: an international journal, 46(3), 353-360, 2018.

[19] M.R. Furtner, J.F. Rauthmann, P. Sachse. Unique self-leadership: A bifactor model approach. Leadership, 11(1), 105-125, 2015.

[20] G.E. Prussia, J.S. Anderson, C.C. Manz. Self - leadership and performance outcomes: the mediating influence of self - efficacy. Journal of Organizational Behavior: The International Journal of Industrial, Occupational and Organizational Psychology and Behavior, 19(5), 523-538, 1998.

[21] F. Alper-Ay, A. Karakaya, K. Y1lmaz. Relations between Self-Leadership and Critical Thinking Skills, Procedia Social and Behavioral Sciences, 207, 29-41, 2015.

[22] F. Şahin. The Convergent, Discriminant, and Concurrent Validity of Scores on the Abbreviated Self-Leadership
Questionnaire, The Journal of Human and Work, 2(2), 91-104, 2015.

[23] C.C. Manz. Mastering Self-Leadership: Empowering Yourself for Personal Excellence. Prentice Hall, New Jersey, 1992.

[24] C.H. Meydan, H. Şeşen. Yapısal eşitlik modellemesi AMOS uygulamaları. Detay Publishing, 2011.

[25] H. Güleç, A. Ayaz. Study of Self Esteem and Professional Self Esteem of Teacher Candidates in terms of Several Variables, Bartin University Journal of Faculty of Education Volume 6, Issue 2, 556-579, 2017.

[26] A. Pierro, A.W. Kruglanski, E.T. Higgins. Regulatory mode and the joys of doing: Effects of "locomotion" and "assessment" on intrinsic and extrinsic task motivation. European Journal of Personality, 20, 355-375, 2006.

[27] C.P. Neck, C.C. Manz. Mastering self-leadership: Empowering yourself for personal excellence. Pearson, 2010.

[28] B.Ç. Garipağaoğlu, B. Güloğlu. Öğretmen adaylarında öz liderlik becerilerinin yordayıcısı olarak ögrenilmiş güçlülük ve denetim odağı. Abant Izzet Baysal University Faculty of Education Journal, 15 (2), 147-162, 2015.

[29] N. Semerci, K. Güney, F. Alper-Ay, Ç. Semerci. Classroom teacher candidates' self-leadership Behaviour, African Journal of Business Management Vol. 4(7), 1381-1385, 2010.

[30] Ö. Erdeveciler, V. Balc1, The Effect of Creative Drama Training on the Self Leadership Skills of Students of the Department of Sports Management, International Refereed Journal of Humanities and Academic Sciences, 21, 37-67, 2017.

[31] E. Bozyigit, Self-Leadership: Volleyball Student-Players and Their Competition Achievement, European Journal of Physical Education and Sport Science, 4, 10, 32-49, 2018. 